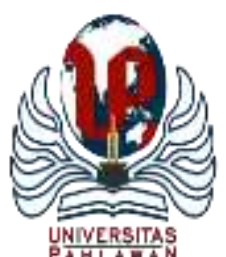

\title{
JURNALBASICEDU
}

Volume 5 Nomor 6 Tahun 2021 Halaman 5995 - 6004

Research \& Learningin Elementary Education https://jbasic.org/index.php/basicedu

\section{Pengembangan Subject Specific Pedagogy Cerita Rakyat Dayak Simpakng pada Kelas Sangsangan Sakolah Adat Arus Kualan}

\author{
Yulita Dewi Purmintasari ${ }^{1 凶}$, Ihsan Nurhakim ${ }^{2}$ \\ Pendidikan Sejarah, IKIP PGRI Pontianak ${ }^{1}$, Pendidikan Geografi, IKIP PGRI Pontianak ${ }^{2}$ \\ E-mail: yulita.dewi46@gmail.com ${ }^{1}$, $\underline{\text { hhsannurhakim08@gmail.com }}^{2}$
}

\begin{abstract}
Abstrak
Pengembangan SSP cerita rakyat Dayak Simpakng pada kelas sangsangan di sakolah adat arus kualan bertujuan untuk mengembangkan SSP berupa bahan ajar dan worksheet cerita rakyat Dayak Simpakng dan untuk mengetahui kelayakan produk hasil pengembangan. Proses penelitian menerapkan metode penelitian pengembangan ADDIE. Hasil validasi bahan ajar cerita rakyat Dayak Simpakng layak digunakan dengan skor rata-rata 4,27 kategori "sangat baik". Hasil validasi worksheet layak digunakan dengan skor rata-rata 4,57 kategori "sangat baik". Hasil evaluasi one to one terhadap bahan ajar "sangat baik" dengan skor rata-rata 4,5, dan respon siswa terhadap worksheet "sangat baik" dengan skor rata-rata 4,47. Hasil evaluasi small group terhadap bahan ajar "sangat baik" dengan skor rata-rata 4,29, dan respon siswa terhadap worksheet "sangat baik" dengan skor rata-rata 4,3
\end{abstract}

Kata Kunci: Subject Specific Pedagogy, Cerita Rakyat, Dayak Simpakng

\begin{abstract}
The development of SSP of Dayak Simpakng folklore in the Sangsangan class at the Kualan Traditional School aims to develop SSP in the form of teaching materials and worksheets of Dayak Simpakng folklore and to determine the feasibility of the product developed. The research process applies the ADDIE development research methodThe results of the validation of the Simpakng Dayak folklore teaching materials are suitable for use with an average score of 4,27 in the "very good" category. The results of the validation worksheet are suitable for use with an average score of 4,57 in the "very good" category. The results of the one-to-one evaluation of teaching materials were "very good" with an average score of 4.5, and student responses to the worksheet were "very good" with an average score of 4.47. The results of the small group evaluation of teaching materials are "very good" with an average score of 4.29, and student responses to the worksheet are "very good" with an average score of 4.3
\end{abstract}

Keywords: Subject Specific Pedagogy, Folktale, Dayak Simpakng

Copyright (c) 2021 Yulita Dewi Purmintasari, Ihsan Nurhakim

$\triangle$ Corresponding author :

Email : yulita.dewi46@gmail.com

DOI : https://doi.org/10.31004/basicedu.v5i6.1742 
5996 Pengembangan Subject Specific Pedagogy Cerita Rakyat Dayak Simpakng pada Kelas Sangsangan Sakolah Adat Arus Kualan - Yulita Dewi Purmintasari, Ihsan Nurhakim

DOI: https://doi.org/10.31004/basicedu.v5i6.1742

\section{PENDAHULUAN}

Perkembangan global yang sangat pesat mendorong berkembangnya pendidikan berbasis kearifan lokal, bahkan dalam pendidikan nor formal muncul pendidikan adat. Pendidikan adat mengajarkan berbagai sistem pengetahuan adat, bahasa, filsafat, kerohanian, pendekatan, sistem dan muatannya (Marti, 2019). Sakolah adat sebagai wujud pendidikan tradisional/pendidikan adat didasarkan pada upaya untuk melestarikan cultural heritage suatu masyarakat. Sekolah adat menjadi wadah berkumpul dengan yang terfokus pada kepeduliaan terhadap pendidikan kebudayaan (Romartu Situngkir, 2020). Sakolah adat Arus Kualan di Simpang Hulu, Ketapang sebagai lembaga pendidikan adat memfasilitasi masyarakat hukum adat Dayak Simpakng dalam menjaga cultural heritage mereka. Selain itu pendidikan adat dibutuhkan untuk menghadapi perkembangan arus globalisasi dan modernisasi yang tidak dapat dielak oleh masyarakat hukum adat dengan dampak perkembangan IPTEK secara pesat melewati batas ruang dan waktu harus disertai dengan penanaman nilainilai untuk meminimalisir dehumanisasi (Putut, 2017). Glocal vison menjadi istilah tepat untuk menggambarkan visi dari sakolah adat Arus Kualan. Glocal vision sebagai pendekatan pembangunan global dengan mengimplementasikan kearifan lokal (Nursalam, 2020). Berdasarkan hasil penelitian Alwasilah menunjukan bahwa ada sejumlah praktik pendidikan adat terbukti ampuh dalam pelestarian cultural heritage diantaranya pada masyarakat adat Kampung Naga dan masyarakat adat Baduy (Maknun, 2017). Sejatinya melalui pendidikan adat terjadi pewarisan budi perkerti, nilai-nilai dan cultural heritage dari generasi ke generasi.

Pendidikan adat yang berdiri di tengah masyarakat berperan dalam Tri Pusat Pendidikan dapat menjadi ujung tombak pendidikan untuk mempertahankan cultural heritage suatu masyarakat, karena dengan budaya dan karakter yang kuat akan mempekuat eksistensi suatu masyarakat dan bangsa. Pendidikan berfungsi untuk mengembangakan pola sikap yang diharapkan masyarakat karena melalui lembaga pendidikan tersampaikan kebudayaan pada generasi muda (Agustini, 2018)). Hakekatnya pendidikan adat merupakan sistem pendidikan dengan tujuan menanamkan value suatu masyarakat tertentu kepada peserta didik, nilai-nilai yang harus ditanamkan diantaranya berupa knowledge, kesadaran, kemauan dan tindakan untuk meneladani nilai-nilai tersebut sehingga adat istiadat akan tetap terjaga, istilah lain sering disebut ilmu pulang (Marti, 2019). Pembelajaran di sakolah adat Arus Kualan mengusung konsep among dan back to nature yang dibagi kedalam 7 kelas, yaitu (1) Kelas Tari/musik/nyanyian Tradisional, (2) Kelas sangsangan (cerita/dongeng tradisional), (3) Kelas menganyam, (4) Kelas makanan dan obat tradisional, (5) Kelas permainan tradisional, (6) Ritual dan nilai-nilai adat, dan (7) Kelas literasi, bahasa, komputer (Purmintasari et al., 2021).

Kelas sangsangan atau kelas bercerita menjadi salah satu langkah penting dalam mempertahankan cultural heritage masyarakat Dayak Simpakng dimana dalam cerita rakyat ditemukan banyak sekali nilai-nilai yang dapat dipalikasikan dalam kehidupan mereka. Hasil penelitian peneliti dengan judul "harmonisasi folktales dan masyarakat adat (Studi Kasus di sakolah adat Arus Kualan)" menunjukkan bahwa di kelas sangsangan terdapat banyak sekali cerita rakyat mulai dari cerita yang bersifat jenaka, sistem pengobatan, sistem perlindungan alam dan lingkungan, pelestarian budaya, dan fabel. Dalam pelaksanaan pembelajaran di kelas sangsangan para pengajar yang terdiri dari tenaga ahli dan tetua masyarakat Dayak Simpakng mengajarkan sesuai dengan kebutuhan anak-anak. Pengajar merupakan orang-orang yang sangat memahami cerita rakyat masyarakat Dayak Simpakng dan cara penyampaiannya. Guru, siswa dan materi pelajaran serta media merupakan elemen utama yang terlibat langsung dalam proses pembelajaran. Guru menjadi core value dalam keberhasilan pencapaian tujuan. Sejalan dengan hasil penelitian Acesta menunjukkan bahwa guru harus memiliki kemampuan pedadogy mengatur pembelajaran, menerapkan metode atau model pembelajaran, menggunakan media dan memanfaatkan waktu secara efektif (Acesta, 2019).

Penelitian yang telah dilakukan pada tahun 2020 yaitu penelitian dengan judul "Pelesatarian Budaya Masyarakat Dayak Simpank Melalui Ecoliterasi (Studi Kasus Sakolah Adat Arus Kualan)" menunjukan 
5997 Pengembangan Subject Specific Pedagogy Cerita Rakyat Dayak Simpakng pada Kelas Sangsangan Sakolah Adat Arus Kualan - Yulita Dewi Purmintasari, Ihsan Nurhakim

DOI: https://doi.org/10.31004/basicedu.v5i6.1742

bahwa sakolah adat Arus Kualan pada kelas sangsangan belum memiliki perangkat pembelajaran yang terintegrasi. Sebuah pembelajaran harus dikemas dan terstruktur sehingga membantu dalam pencapaian tujuan pendidikan baik ranah kognitif, afektif dan psikomotorik (Hidayat et al., 2019). Terintegrasi dan terstrukturnya pembelajaran disebut dengan istilah Subject spesific Pedagogy (SSP) yang diwujudkan dalam silabus, RPP (lesson design), bahan ajar, perangkat penilaian (Purwanti, 2016). Pengembangan SSP berfokus pada isi dan pedagogi, dengan elemen kunci 1) pengetahuan tentang materi kajian, 2) pemahaman dan implikasi yang berhubungan antar subjek, 3) pengetahuan umum pedagogi, 4) pengetahuan kurikulum, 5) pengetahuan tentang isi dan tujuan Pendidikan (Handayani \& Wilujeng, 2017).

Hasil penelitian Handayani menyimpulkan bahwa SSP bersifat dinamis dikarenakan SPP dapat mengalami perubahan melalui respon siswa dan mata pelajaran itu sendiri (Darma et al., 2020). Sakolah adat Arus Kualan yang mengusung pendidikan adat berbasis kearifan lokal melalui SSP dapat menciptakan tujuan pendidikan yang relevan dengan perkembangan masa depan. Pembangunan karakter siswa yang berbasis pada kearifan lokal dapat menjadikannya sebagai anggota masyarakat adat yang cerdas, kreatif, kompetitif, inovatif dan terbuka dengan tetap mempertahankan cultural heritage dan memegang teguh nilai-nilai kearifan lokal yang akan berkontribusi dalam membangun budaya masyarakat.

Berdasarkan latar belakang tersebut maka akan dilakukan pengembangan produk subject specific pedagogy cerita rakyat Dayak Simpakng pada kelas Sangsangan di Sakolah adat Arus Kualan. Penelitian ini bertujuan untuk mengetahui proses pengambangan produk dan kelayakan produk hasil pengembangan sehingga didapatkan produk yang layak untuk digunakan dalam pembelajaran.

\section{METODE PENELITIAN}

Proses penelitian memiliki langkah-langkah yang sangat jelas dengan menerapkan metode research and development dengan hasil akhir berupa produk, yaitu produk dari subject specific pedadogy. Metode pengembangan penelitian mengadopsi model pengembangan deskriptif prosedural, yang dalam kegiatannya akan dilakukan secara bertahap untuk menghasilkan produk yang valid, realiabil dan kredibel. Pengembangan didasarkan pada ADDIE karya Dick dan Carrey. Dalam proses pengembanganya ADDIE dilakukan lima tahap pengembangan yaitu Analyze, Design, Develop, Implement dan Evaluate (Chairudin \& Dewi, 2021).

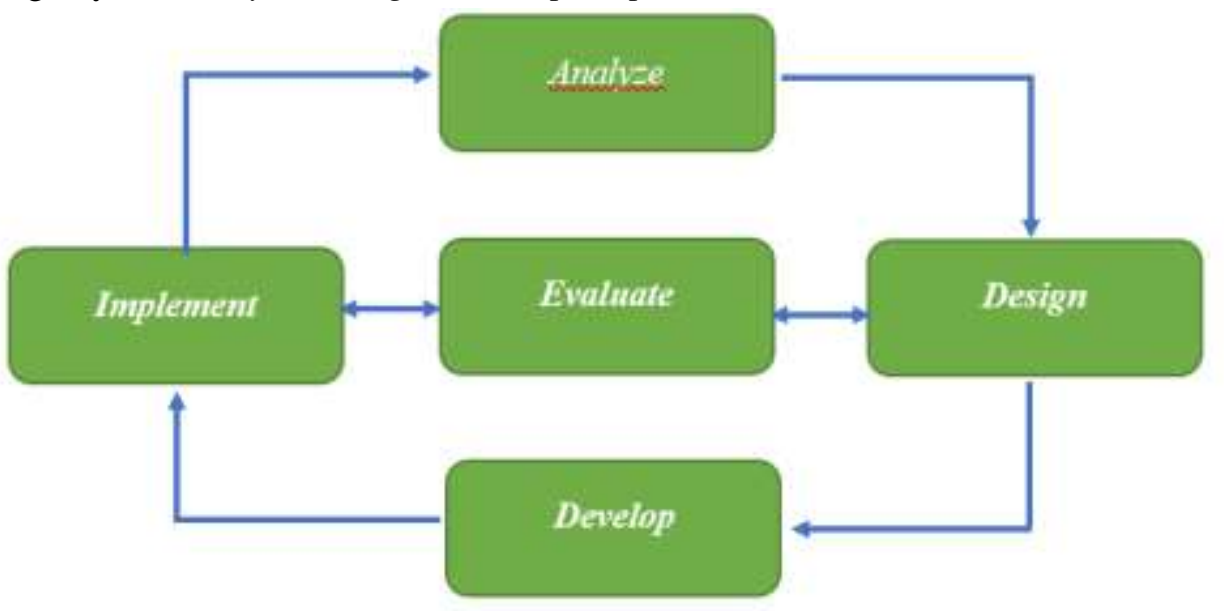

Gambar 1. Model Pengembangan ADDIE

(Tegeh et al., 2015)

Variabel Penelitian ini yaitu (1) Subject specific pedagogy, diartikan sebagai packaging sebuah perangkat pembelajaran, (2) cerita rakyat diartikan sebagai suatu cerita yang berkembang dalam masyarakat dan menjadi dasar acuan norma bagi masyarakat (Asnawi, 2020). 
5998 Pengembangan Subject Specific Pedagogy Cerita Rakyat Dayak Simpakng pada Kelas Sangsangan Sakolah Adat Arus Kualan - Yulita Dewi Purmintasari, Ihsan Nurhakim

DOI: https://doi.org/10.31004/basicedu.v5i6.1742

Penelitian pengembangan yang akan dilakukan menggunakan subjek penelitian yaitu pengajar, peserta didik sakolah adat Arus Kualan, tetua adat dan masyarakat Dayak Simpakng. Teknik pengumpulan data penelitian ini menggunakan observasi, komunikasi langsung, dan dokumen, dengan intrumennya berupa panduan observasi, panduan wawancara, dan lembar validasi ahli. Evidensi yang yang didapat akan dilakukan analisis data dengan menggunakan teknik deskriptif kuantitatif. Kriteria kualitas produk subject specific pedadogy akan ditentukan berdasarkan persentase dari validator yang akan dikonversikan dalam kriteria persentase skor penilaian menurut (Rahman et al., 2020)

\section{Tabel 1. Konversi Data Skala 5}

\begin{tabular}{ccc} 
Score Interval & Value & Categories \\
\hline $\mathrm{X}>\mathrm{x}_{\mathrm{i}}+1,5 \mathrm{SB}_{\mathrm{i}}$ & $\mathrm{A}$ & Very good \\
\hline $\mathrm{x}_{\mathrm{i}}+0,5 \mathrm{SB}<\mathrm{X} \leq \mathrm{x}_{\mathrm{i}}+1,5 \mathrm{SB}_{\mathrm{i}}$ & $\mathrm{B}$ & Good \\
\hline $\mathrm{x}_{\mathrm{i}}-0,5 \mathrm{SB}_{i}<\mathrm{X} \leq \mathrm{x}_{\mathrm{i}}+0,5 \mathrm{SB}$ & $\mathrm{C}$ & Good enough \\
\hline $\mathrm{x}_{\mathrm{i}}-1,5 \mathrm{SB}_{\mathrm{i}}<\mathrm{X} \leq \mathrm{x}_{\mathrm{i}}-0,5 \mathrm{SB}_{\mathrm{i}}$ & $\mathrm{D}$ & Not good \\
\hline $\mathrm{X} \leq \mathrm{x}_{\mathrm{i}}-1,5 \mathrm{SB}_{\mathrm{i}}$ & $\mathrm{E}$ & Very poor \\
\hline
\end{tabular}

\section{Keterangan:}

$\mathrm{Xi} \quad=$ Rerata skor ideal $=1 / 2$ (skor maksimal ideal + skor minimal ideal)

Sbi $\quad=$ Simpangan baku ideal $=1 / 6$ (skor maksimal ideal-skor minimal ideal $)$

$\mathrm{X} \quad=$ Skor aktual

\section{HASIL DAN PEMBAHASAN}

\section{Pengembangan Subject Specific Pedagogy Cerita Rakyat Dayak Simpakng}

\section{Analyze}

Pengembangan Subject Specific Pedagogy cerita rakyat Dayak Simpakng berupa bahan ajar dan workseheet kelas sangsangan, pada tahap analisis harus menganalisis empat hal, yaitu menganalisis peserta didik (di mana mereka berada, keterampilan dan kebutuhan mereka, dll), analisis instruksional (untuk memberikan langkah-langkah yang diperlukan dan menyajikan peluang, membuat tujuan instruksional (bertujuan untuk menentukan hasil akhir yang diinginkan), dan menganalisis tujuan pembelajaran untuk mengukur pencapaian tujuan (Aldoobie, 2015). Melalui analisis kebutuhan akan dapat mengidentifikasi kesesuaian produk dengan tujuan pendidikan, visi sekolah, kebutuhan stakeholder dan kebutuhan peserta didik. Analyze dilakukan untuk mendapatkan gambaran lingkungan di sakolah adat Arus Kualan, masyarakat, karakter siswa. Dari hasil analyze didapatkan tujuan didirikannya sakolah adat dan harapan yang harus dicapai siswa. Tujuan sekolah tidak lepas dari pemikiran thing globally act locally, Siswa memiliki pemikiraan global dengan mengimplementasikan kearifan lokal, sehingga cultural heritage suatu masyarakat tidak terlupakan (Nursalam, 2020). Siswa diharapkan untuk menjadi bagian dari masyarakat modern dengan tetap menjaga dan melestarikan cultural heritage masyarakat Dayak Simpakng, sehingga siswa memaknai dan melestarikan cerita rakyat masyakarat Dayak Simpakng. Dalam tahap ini didapatkan tujuan pembelajaran kelas sangsangan, yaitu:

a. Siswa mengetahui berbagai cerita rakyat masyarakat Dayak Simpakng

b. Siswa memahami nilai-nilai/ pesan moral dari cerita rakyat

c. Siswa mampu memaknai dan mengaplikasikan nilai-nilai/ pesan moral cerita rakyat dalam kehidupan sehari-hari

d. Siswa mampu melestarikan berbagai cerita rakyat 
5999 Pengembangan Subject Specific Pedagogy Cerita Rakyat Dayak Simpakng pada Kelas Sangsangan Sakolah Adat Arus Kualan - Yulita Dewi Purmintasari, Ihsan Nurhakim

DOI: https://doi.org/10.31004/basicedu.v5i6.1742

\section{Design}

Tahap lanjutan dari pengembangan bahan ajar yaitu design, dalam design dilakukan untuk merancang SSP. SSP yang dikembangkan adalah bahan ajar dan worksheet akan dibuat. Didapatkannya draft awal merupakan hasil akhir dari tahapan design. Pada tahap design terdapat dua langkah penting yaitu: 1) pemilihan format awal mulai dari sampul hingga bibliografi, kompetensi yang hendak dicapai, Tahap pemilihan format dalam pengembangan SSP untuk mendesain isi pembelajaran, pemilihan model, pendekataan dan sumber belajar. 2) penyusunan design awal isi yang berlandaskan pada studi literatur, serta hasil wawancara narasumber. Struktur design awal harus terdapat kompetensi dasar, indikator, tujuan pembelajaran, materi pembelajaran, tugas terstruktur, serta referensi (Desmawati, 2018). Prosedur yang dilakukan sesuai dengan tahapan ADDIE, pada tahap design akan didapatkan desain awal yang terdiri dari: task inventory diagram, a complate set of performance objectives, a complete set of test items, a testing strategy, and return on investmen proposal (Branch, 2009).

\section{Develop}

Tahap develop dilakukan sebagai realisasi dari design dalam bentuk draft bahan ajar dan worksheet. Bahan ajar sebagai bentuk bantuan kepada siswa belajar mandiri. Bahan ajar dihadirkan dengan berbagai karakteristik sehingga mendukung siswa belajar mandiri menggunakan bahan ajar (Widiana \& Rosy, 2021). Karakteristik sebuah bahan ajar yaitu selft instruction, selft contained, stand alone, adaptif, dan user friendly (Daryanto, 2013). Bahan ajar meliputi sampul, kata pengantar, daftar isi, pengantar (SK, KD, Indikator, tujuan pembelajaran), isi materi (Materi, deskripsi dan aktivitas), daftar pustaka. Bahan ajar sebagai bahan bantu belajar mandiri siswa disusun secara atraktif untuk menarik siswa belajar. Bahan ajar cerita rakyat Dayak Simpakng memuat KD memahami nilai-nilai/ pesan moral dari cerita rakyat, dan indikator a) menyimpulkan isi dan makna yang terkandung dalam teks cerita rakyat, b) mengidentifikasi nilai-nilai yang menjadi nilai pokok dalam cerita rakyat.

Worksheet merupakan lembar kerja/kegiatan siswa yang didalamnya berisi lembaran kegiatan untuk menyelesaiakan tugas siswa (Prastowo, 2011). Worksheet difokuskan pada cerita rakyat Dayak Simpakng yang harus diceritakan kembali oleh siswa. Penyusunan worksheet sesuai dengan tujuannya, yaitu untuk a) menyajikan salah satu materi bahan ajar sehingg memudahkan siswa untuk memahami materi yang diberikan, b) menyajikan tugas-tugas untuk meningkatkan penguasaan materi, c) melatih kemandirian belajar siswa, d) membantu guru dalam pemberian tugas (Prastowo, 2011).

Worksheet hendaknya memenuhi tiga aspek pokok dalam pengembanganya, yaitu aspek dikdatis, aspek kontruksi, dan aspek Teknik. Dalam aspek didaktik harus mengukuti asas belajar mandiri yang efektif, yang meliputi:

a. Memperhatikan perbedaan individual karena worksheet digunakan oleh semua siswa

b. Menenkankan pada proses

c. Memiliki variasi stimulus

d. Mengembangkan komunikasi moral, sosial, dan estetika pada siswa

Worksheet cerita rakyat Dayak Simpakng memuat memuat stimulus bagi siswa agar mampu memahami nilai-nilai dalam materi cerita rakyat. Siswa diminta untuk menyimpulkan cerita rakyat yang telah mereka dengarkan dan mereka baca. Dalam worksheet diberikan kebebasan kepada siswa untuk menceritakan kembali cerita rakyat tersebut sesuai dengan Bahasa anak dan kemampuan anak dalam menangkap pesan dan makna dari cerita rakyat. Siswa diberikan kesempatan untuk mengaplikasikan dan menjelaskan contohnya dalam kehidupan sehari-hari mereka.

Aspek Teknik berkaitan dengan tata tulis penulisan worksheet yang meliputi:

a. Menggunakan huruf yang serasi dengan gambar

b. Gambar dapat menyampaikan pesan secara efektif 
6000 Pengembangan Subject Specific Pedagogy Cerita Rakyat Dayak Simpakng pada Kelas Sangsangan Sakolah Adat Arus Kualan - Yulita Dewi Purmintasari, Ihsan Nurhakim

DOI: https://doi.org/10.31004/basicedu.v5i6.1742

c. Kombinasi selaras antara tulisan dan gambar

Aspek konstruksi berhubungan dengan penyusunan kalimat, kosakata dan tingkat kesuakaran, sehingga dalam hal ini sebuah worksheet haruslah:

a. Bahasa yang sesuai dengan tingkat perkembangan siswa

b. Struktur kalimat lugas dan jelas

c. Urutan pelajaran yang sesuai dengan tingkat kemampuan siswa

d. Menghindari pertanyaan yang terlalu terbuka

e. mmemberi kekeluasaan pada siswa

f. Menggunakan banyak ilustrasi

g. Memiliki tujuan yang jelas

Worksheet cerita rakyat Dayak Simpakng dituliskan dalam kalimat yang sederhana didasarkan pada karakter siswa sakolah adat yang sangat variatif. Pembelajaran di sakolah ada arus kualan yang mengusung pembelajaran among tidak membedakan siswa berdasarkan usia, semua anak dengan usia TK hingga SMA belajar bersama sama (Purmintasari et al., 2021). Hal ini dikarenakan tujuan utama pendidikan adat bukanlah orientasi nilai kognitif akan tetapi lebih pada nilai-nilai kehidupan yang dapat dimaknai dalam kehidupan mereka. Dan saling membantu antar siswa adalah hal sangat diharapkan oleh sakolah adar, dimana belajar Bersama-sama siswa yang jauh lebih besar/dewasa dapat mendampingi adik-adik mereka untuk lebih memaknai nilai-nilai dari setiap materi.

\section{Implement}

Produk Subject specific Pedagogy Cerita Rakyat Dayak Simpakng berupa draft bahan ajar dan worksheet akan dilakukan validasi. Beberapa ahli melakukan validasi produk yang terdiri dari ahli media, ahli materi, dan pengajar kelas sangsangan di Sakolah Adat Arus Kualan. Hasil validasi menjadi bahan kajian untuk memperbaiki produk dan draft hasil pengembangan akan disempurnakan menjadi produk yang lebih halus. Setelah di validasi ahli maka akan dilakukan uji coba pada siswa. Tahap implement produk yang telah tervalidasi akan diterapkan dalam pembelajaran guna mengetahui kualitas dan efektifitas produk.

Bahan ajar dan worksheet yang telah divalidasi dan di uji coba pada siswa akan dilakukan implementasi dalam pembelajaran di kelas sangsangan. Sesuai dengan kompetensi dasar pembelajaran sangsangan siswa harus mampu untuk memaknai dan melestarikan cerita rakyat masyarakat Dayak Simpakng, maka di kelas sangsangan juga belajar untuk menceritakan kembali cerita rakyat tersebut dan dengan nada penyampaiannya. Siswa menyampaikan nilai-nilai dan makna dari cerita rakyat yang disampaikan, dan dalam kehidupan seharihari mereka menerapkan makna dari cerita rakyat tersebut. Siswa mengetahui berbagai cerita rakyat masyarakat Dayak Simpank, siswa memahami nilai-nilai/ pesan moral dari cerita rakyat, siswa mampu memaknai dan mengaplikasikan nilai-nilai/ pesan moral cerita rakyat dalam kehidupan sehari-hari, sehingga siswa mampu melestarikan berbagai cerita rakyat masyarakat Dayak Simpakng. Hasil validasi dari ahli terhadap bahan ajar dan worksheet cerita rakyat dayak simpank yaitu layak digunakan.

\section{Evaluate}

Produk hasil pengembangan yang telah di validasi dan di implementasi maka akan dilakukan evaluasi terhadap produk hasil pengembangan. Dalam penelitian ini dilakukan evaluasi formatif, untuk memperbaiki produk pengembangan yang dihasilkan. Evaluasi formatif dilakukan dalam setiap tahapan pengembangan untuk mengetahui produk telah dikembangkan sesuai dengan standarnya (Angko \& Mustaji, 2013). Ketika pada satu tahapan hasilnya tidak sesuai maka harus diulangi kembali untuk meningkatkan kualitas produk. Proses pengulangan perancangan dalam setiap tahapan disebut dengan pendekatan interative (Angko \& Mustaji, 2013). Selain evaluasi pada setiap tahapannya akan dilakukan evaluasi one to one yang dilakukan pada 3 orang siswa, dan small group yang dilakukan pada 5-10 siswa (Prastyo et al., 2019). 
6001 Pengembangan Subject Specific Pedagogy Cerita Rakyat Dayak Simpakng pada Kelas Sangsangan Sakolah Adat Arus Kualan - Yulita Dewi Purmintasari, Ihsan Nurhakim

DOI: https://doi.org/10.31004/basicedu.v5i6.1742

\section{Uji Kelayakan Produk SSP Pendidikan Adat}

Uji kelayakan produk SSP hasil pengembangan berupa bahan ajar dan worksheet cerita dilakukan melalui validasi ahli, evaluasi one to one, dan evaluasi small group. hasil evaluasi digunakan untuk mengetahui efektifitas dan efisien bahan ajar dan worksheet dalam mencapai tujuan yang telah ditetapkan dalam analyze.

Tabel 2. Validasi Bahan Ajar (SSP) Cerita Rakyat Dayak Simpakng

\begin{tabular}{|c|c|c|c|c|c|c|}
\hline \multirow{2}{*}{ No } & \multirow{2}{*}{ Item } & \multirow{2}{*}{ V1 } & \multirow{2}{*}{$\mathrm{V} 2$} & \multirow{2}{*}{ V3 } & \multicolumn{2}{|c|}{ Keterangan } \\
\hline & & & & & Skor & kategori \\
\hline 1 & Kelayakyakan isi & 4,38 & 4,15 & 4,25 & 4,26 & SB \\
\hline 1.a & Kesesuaian isi/materi dengan Standar Kompetensi & 4 & 4 & 4 & 4 & B \\
\hline 1.b & Keakuratan materi & 4,38 & 4,25 & 4,5 & 4,38 & SB \\
\hline 1.c & Pendukung materi pembelajaran & 4,67 & 4,33 & 4,5 & 4,5 & SB \\
\hline $1 . \mathrm{d}$ & Kemutakhiran materi & 4,5 & 4 & 4 & 4,17 & $\mathrm{~B}$ \\
\hline 2 & Kelayakan penyajian & 4,92 & 4,38 & 4,04 & 4,45 & SB \\
\hline $2 . \mathrm{a}$ & Teknik Penyajian & 5 & 4 & 3,66 & 4,22 & SB \\
\hline $2 . \mathrm{b}$ & Pendukung penyajian & 4,71 & 4 & 4,14 & 4,28 & SB \\
\hline 2.c & Penyajian pembelajaran & 5 & 5 & 4 & 4,67 & SB \\
\hline 2.d & Kelengkapan penyajian & 5 & 4,5 & 4,33 & 4,61 & SB \\
\hline 3 & Kelayakan bahasa & 4,42 & 3,94 & 4,42 & 4,26 & SB \\
\hline 3.a & Lugas & 5 & 3,66 & 4 & 4,22 & SB \\
\hline 3.b & Komunikatif & 4.5 & 4 & 5 & 4,5 & SB \\
\hline 3.c & Dialogis dan interaktif & 4 & 4 & 5 & 4,33 & SB \\
\hline 3.d & Kesesuaian dengan perkembangan peserta didik & 4 & 4 & 4 & 4 & B \\
\hline 3.e & Keruntutan dan keterpaduan alur & 4 & 4 & 4,5 & 4,17 & $\mathrm{~B}$ \\
\hline 3.f & Penggunaan istilah, simbol dan ikon & 5 & 4 & 4 & 4,33 & SB \\
\hline 4 & Interaktifitas & 4 & 4 & 4,41 & 4,14 & $\mathrm{~B}$ \\
\hline $4 . \mathrm{a}$ & Mendorong interaktifitas siswa & 5 & 4 & 4 & 4,33 & SB \\
\hline 4.b & Memunculkan hubungan timbal balik & 4 & 4 & 5 & 4,33 & SB \\
\hline \multicolumn{2}{|c|}{ Rata-Rata } & 4,57 & 4 & 4,23 & 4,27 & SB \\
\hline \multicolumn{2}{|c|}{ Kategori } & SB & B & SB & SB & \\
\hline
\end{tabular}

Berdasarkan tabel 2 menunjukkan bahwa hasil validasi bahan ajar cerita rakyat Dayak Simpakng oleh tiga validator secara keseluruhan layak digunakan sebagai bahan ajar dengan kategori "sangat baik" dengan rata-rata skor keseluruhan yaitu 4,27. Validasi bahan ajar terdiri dari 4 aspek yaitu aspek kelayakan isi, aspek penyajian, aspek bahasa dan interaktifitas. Skor rata-rata aspek kelayakan isi yaitu 4,26 dengan konversi nilai "sangat baik". Indikator aspek kelayakan isi terdiri dari: kesesuaian isi/materi dengan Standar Kompetensi, keakuratan materi, pendukung materi pembelajaran, kemutakhiran materi. Skor rata-rata kelayakan penyajian 4,45 dengan konversi nilai "sangat baik. Indikator aspek kelayakan penyajian yaitu teknik penyajian, pendukung penyajian, penyajian pembelajaran, dan kelengkapan penyajian. Skor rata-rata aspek kelayakan Bahasa 4,26 dengan konversi nilai "sangat baik". Indikator aspek kelayakan bahasa yaitu lugas, komunikatif, dialogis dan interaktif, kesesuaian dengan perkembangan peserta didik, keruntutan dan keterpaduan alur, dan penggunaan istilah, simbol dan ikon. Rata-rata skor interaktifitas 4,14 dengan konversi nilai "baik'. Indikator aspek interaktifitas yaitu mendorong interaktifitas siswa, dan memunculkan hubungan timbal baik.

Tabel 3. Validasi Worksheet (SSP) Cerita Rakyat Dayak Simpakng

\begin{tabular}{clccccc}
\hline \multirow{2}{*}{ No } & \multirow{2}{*}{ Aspek penilaian } & \multirow{2}{*}{ V1 } & \multirow{2}{*}{ V2 } & \multirow{2}{*}{ V3 } & \multicolumn{3}{c}{ Keterangan } \\
\cline { 5 - 7 } & & 4,33 & 4,5 & 4,67 & 4,5 & Skor \\
\hline 1 & Kesesuaian Materi & 5 & 4 & 4 & 4,33 & SB \\
\hline $1 . \mathrm{a}$ & Kesesuaian dengan SK dan KD & 5 & 4 & 4 & 4,33 & SB \\
\hline $1 . \mathrm{b}$ & Kesesuaian dengan kebutuhan peserta didik & & & &
\end{tabular}


6002 Pengembangan Subject Specific Pedagogy Cerita Rakyat Dayak Simpakng pada Kelas Sangsangan Sakolah Adat Arus Kualan - Yulita Dewi Purmintasari, Ihsan Nurhakim

DOI: https://doi.org/10.31004/basicedu.v5i6.1742

\begin{tabular}{clccccc}
\hline 1.c & Kebenaran isi & 4 & 5 & 5 & 4,67 & SB \\
\hline 1.d & Manfaat untuk penambahan wawasan pengetahuan & 4 & 4 & 5 & 4,33 & SB \\
\hline 1.e & Kesistematisan urutan materi & 5 & 5 & 5 & 5 & SB \\
\hline 1.f & Kesesuaian dengan nilai-nilai karakter & 4 & 5 & 5 & 4,67 & SB \\
\hline 2 & Kesesuaian dengan syarat konstruksi & 4,67 & 4,33 & 4,33 & 4,44 & SB \\
\hline 2.a & Kejelasan Bahasa yang digunakan & 5 & 4 & 5 & 4,67 & SB \\
\hline 2.b & Kesesuaian dengan kaidah Bahasa Indonesia & 5 & 4 & 4 & 4,33 & SB \\
\hline 2.c & $\begin{array}{l}\text { Kesesuaian pertanyaan yang digunakan dengan tingkat } \\
\text { kemampuan peserta didik }\end{array}$ & 4 & 5 & 4 & 4,33 & SB \\
\hline 3 & Kesesuaian dengan syarat teknis & 5 & 4,5 & 4 & 4,5 & SB \\
\hline 3.a & Kejelasan tampilan worksheet & 5 & 4 & 4 & 4,33 & SB \\
\hline 3.b & Kemenarikan tampilan worksheet & 5 & 5 & 4 & 4,67 & SB \\
\hline 4 & Pembentukan karakter & 5 & 4,5 & 5 & 4,83 & SB \\
\hline 4.a & $\begin{array}{l}\text { Kebermanfaatan cerita rakyat untuk membentuk karakter } \\
\text { peserta didik }\end{array}$ & 5 & 4 & 5 & 4,67 & SB \\
\hline 4.b & Kebermanfaatan kata-kata motivasi & & & & \\
\hline & Rata-Rata & 5 & 5 & 5 & 5 & SB \\
\hline & Kategori & 4,75 & 4,45 & 4,5 & 4,57 & SB \\
\hline
\end{tabular}

Berdasarkan tabel 3 menunjukkan bahwa hasil validasi worksheet Cerita rakyat Dayak Simpakng dari tiga validator dapat digunakan sebagai lembar kerja siswa dengan kategiri "sangat baik" dengan rata-rata skor 4,57. Aspek penilaian worksheet terdiri dari kesesuaian materi, kesesuaian dengan syarat konstruktif, kesesuaian denngan syarat teknis, dan pembentukan karakter. Skor rata-rata aspek kesesuaian materi 4,5 dengan konversi nilai "sangat baik'. Indikator aspek kesesuaian materi yaitu kesesuaian dengan SK dan KD, kesesuaian dengan kebutuhan peserta didik, kebenaran isi, manfaat untuk penambahan wawasan pengetahuan, kesistematisan urutan materi, Kesesuaian dengan nilai-nilai karakter. Skor rata-rata kesesuaian dengan syarat konstruksi 4,44 dengan konversi nilai "sangat baik". Indikator aspek Kesesuaian dengan syarat konstruksi yaitu kejelasan Bahasa yang digunakan, Kesesuaian dengan kaidah Bahasa Indonesia, Kesesuaian pertanyaan yang digunakan dengan tingkat kemampuan peserta didik. Skor rata-rata kesesuaian dengan syarat teknis 4,5 dengan konversi nilai "sangat baik". Indikator aspek kesesuaian dengan syarat teknis yaitu, Kejelasan tampilan worksheet, dan Kemenarikan tampilan worksheet. Skor rata-rata pembentukan karakter 4,83 dengan konversi nilai "sangat baik". Indikator aspek pembentukan karakter yaitu kebermanfaatan cerita rakyat untuk membentuk karakter peserta didik, dan kebermanfaatan kata-kata motivasi. Validator memberikan beberapa catatan dalam worksheet, yaitu untuk memeperjelas Bahasa yang digunakan dalam sehingga sesuai dengan kaidah Bahasa Indonesia.

Tabel 4. Evalusai one to one

\begin{tabular}{cccc}
\hline No & SSP & Skor Aktual & Kategori \\
\hline 1 & Bahan Ajar & 4,5 & SB \\
\hline 2 & Worksheet & 4,47 & SB \\
\hline
\end{tabular}

Evaluasi one to one dilakukan pada 3 oranng siswa. Respon siswa terdapat bahan ajar cerita rakyat Dayak Simpakng menunjukan hasil "sangat baik" dengan skor rata-rata 4,5. Aspek penilaian bahan ajar yaitu aspek materi, aspek teks/Bahasa, aspek gambar dan pembelajaran. Respon siswa terhadap worksheet cerita rakyat Dayak Simpakng menunjukan hasil "sangat baik" dengan skor rata-rata 4,47. Aspek penilaian worksheet yaitu kesesuaian materi, kesesuaian dengan syarat konstruksi, kesesuaian dengan syarat teknis, dan pembentukan karakter. 

Sakolah Adat Arus Kualan - Yulita Dewi Purmintasari, Ihsan Nurhakim DOI: https://doi.org/10.31004/basicedu.v5i6.1742

Tabel 5. Evalusai small group

\begin{tabular}{cccc}
\hline No & SSP & Skor Aktual & Kategori \\
\hline 1 & Bahan Ajar & 4,29 & SB \\
\hline 2 & Worksheet & 4,3 & SB \\
\hline
\end{tabular}

Evaluasi small group dilakukan pada 10 siswa. Hasil evaluasi bahan ajar cerita rakyat Dayak simpakng menunjukan hasil "sangat baik" dengan skor rata-rata 4,29. Aspek penilaian bahan ajar yaitu aspek materi, aspek teks/bahasa, aspek gambar dan pembelajaran. Respon siswa terhadap worksheet cerita rakyat Dayak simpakng menunjukan hasil "sangat baik" dengan skor rata-rata 4,3. Aspek penilaian worksheet yaitu kesesuaian materi, kesesuaian dengan syarat konstruksi, kesesuaian dengan syarat teknis, dan pembentukan karakter.

\section{KESIMPULAN}

Benang merah penelitian dalam proses pengembangan subject specific pedagogy cerita rakyat Dayak Simpakng melalui tahapan pengembangan ADDIE dengan hasil akhir produk berupa bahan ajar dan worksheet cerita rakyat Dayak Simpakng. Hasil validasi bahan ajar cerita rakyat Dayak Simpakng layak digunakan dengan skor rata-rata 4,27 kategori "sangat baik". Hasil validasi worksheet layak digunakan dengan skor rata-rata 4,57 kategori "sangat baik". Hasil evaluasi one to one terhadap bahan ajar "sangat baik" dengan skor rata-rata 4,5, dan respon siswa terhadap worksheet "sangat baik" dengan skor rata-rata 4,47. Hasil evaluasi small group terhadap bahan ajar "sangat baik" dengan skor rata-rata 4,29, dan respon siswa terhadap worksheet "sangat baik" dengan skor rata-rata 4,3 .

\section{UCAPAN TERIMA KASIH}

Terima kasih kepada IKIP PGRI Pontianak yang telah memberikan bantuan dana dalam penelitian ini, terima kasih untuk yayasan dan sakolah adat Arus Kualan yang sudah menjadi mitra peneliian.

\section{DAFTAR PUSTAKA}

Acesta, A. (2019). Development Of Subject Specific Pedagogy In Integrated Science Learning In Elementary School. Journal Of Physics: Conference Series, 1318(1), 1-6. Https://Doi.Org/10.1088/1742$6596 / 1318 / 1 / 012112$

Agustini, N. M. S. (2018). Tripusat Pendidikan Sebagai Lembaga Pengembangan Teori Pembelajaran Bagi Anak. Magistra: Media Pengembangan Ilmu Pendidikan Dasar Dan Keislaman, 9(2), 25-46. Https://Doi.Org/10.31942/Mgs.V9i2.2543

Aldoobie, N. (2015). Addie Model. American International Journal Of Contemporary Research, 5(6), 68-72. Http://Www.Aijcrnet.Com/Journal/Index/969

Angko, N., \& Mustaji. (2013). Pengembangan Bahan Ajar Dengan Model Addie Untuk Mata Pelajaran Matematika Kelas 5 Sds Mawar Sharon Surabaya. Jurnal Kwangsan, 1(1), 1-15.

Asnawi. (2020). Kategori Dan Fungsi Sosial Teks Cerita Rakyat Mayarakat Banjar Hulu: Sebagai Pengukuh Warisan Kebudayaan Lokal Bangsa. Jurnal Sastra Indonesia, 9(3), 212-221. Https://Journal.Unnes.Ac.Id/Sju/Index.Php/Jsi/Article/View/41939/17542

Branch, R. M. (2009). Instructional Design: The Addie Approach. Springer. Https://Doi.Org/10.5005/Jp/Books/10200_4

Chairudin, M., \& Dewi, R. M. (2021). Pengembangan Bahan Ajar Buku Saku Digital Berbasis Problem Based 
6004 Pengembangan Subject Specific Pedagogy Cerita Rakyat Dayak Simpakng pada Kelas Sangsangan Sakolah Adat Arus Kualan - Yulita Dewi Purmintasari, Ihsan Nurhakim

DOI: https://doi.org/10.31004/basicedu.v5i6.1742

Learning Pada Mata Pelajaran Ekonomi. Edukatif: Jurnal Ilmu Pendidikan, 3(3), 951-962. Https://Doi.Org/Https://Doi.Org/10.31004/Edukatif.V3i3.491

Darma, Y., Suratman, D., Ahmad Yani, T., \& Susiaty, U. D. (2020). Balance Of Soft Skills And Hard Skills: Development Of Subject Specific Pedagogic Based On Heuristic Strategy With Character Contents In Learning. Aip Conference Proceedings, 2268, 1-11. Https://Doi.Org/10.1063/5.0019123

Daryanto. (2013). Menyusun Modul Bahan Ajar Untuk Persiapan Guru Dalam Mengajar. Gava Media.

Desmawati, R. (2018). Tahap Design Bahan Ajar Fisika Sma Terintegrasi Iman Dan Takwa Berbasis Model Discovery Learning Pada Materi Suhu. Natural Science Jurnal, 4(1), 516-526.

Handayani, S., \& Wilujeng, I. (2017). Pengembangan Subject Specific Pedagogy Berbasis Inkuiri Untuk Meningkatkan Keterampilan Proses Dan Motivasi Belajar Ipa. Scholar.Archive.Org, 5(1), 22-35. Https://Doi.Org/10.21831/Jpms.V5i1.13537

Hidayat, T., Firdaus, E., \& Momod Abdul Somad. (2019). Model Pengembangan Kurikulum Tyler Dan Implikasinya Dalam Pembelajaran Pendidikan Agama Islam Di Sekolah. 5(2), 197-218. Https://Doi.Org/Doi: Http://Dx.Doi.Org/10.24014/Potensia.V5i2.6698

Maknun, J. (2017). Konsep Sains Dan Teknologi Pada Masyarakat Tradisional Di Provinsi Jawa Barat, Indonesia. Mimbar Pendidikan: Jurnal Indonesia Untuk Kajian Pendidikan, 2(2), 127-142. Https://Doi.Org/Doi: Https://Doi.Org/10.2121/Mp.V2i2.877

Marti, S. (2019). Ilmu Pulang: Sebuah Buku Tentang Pendidikan Adat. Lifemosaic Publishing.

Nursalam. (2020). Glocal Vision To Deconstruct Internationalization In Indonesian Higher Education. Journal Of Social Studies Education Research, 11(1), 137-152.

Prastowo. (2011). Bahan Ajar Inovatif. Diva Press.

Prastyo, A. A., Sriwijaya, U., \& Pengembangan, P. (2019). Pengembangan Petunjuk Praktikum Pada Mata Kuliah Kinematika Dan Dinamika Di Program Studi The Practicum Instructions Development In Kinematics And Dynamics Courses Of The Mechanical Engineering Education Study Program Of Sriwijaya. Jurnal Pendidikan Teknik Https://Ejournal.Unsri.Ac.Id/Index.Php/Ptm/Article/View/6976

Purmintasari, Y. D., Nurhakim, I., Rivasintha, E., \& Firmansyah, H. (2021). The Arus Kualan Traditional School: Preservation Of Dayak Simpank Environmental And Cultural Heritage. Iop Conference Series: Earth And Environmental Science, 747(1), 1-7. Https://Doi.Org/10.1088/1755-1315/747/1/012049

Purwanti, E. (2016). Implementasi Penggunaan Ssp(Subject Specific Pedagogy) Tematik Integratif Untuk Menanamkan Tanggung Jawab, Kerja Keras, Dan Kejujuran. Terampil: Jurnal Pendidikan Dan Pembelajaran Dasar, 3(2), 157-180. Https://Doi.Org/10.24042/Terampil.V3i2.1194

Putut, S. (2017). Integrasi Nilai-Nilai Kearifan Budaya Lokal. Seminar Nasional Keiindonesiaan Ii Tahun 2017 "Strategi Kebudayaan Dan Tantangan Ketahanan Nasional Kontemporer, 228-240.

Rahman, N., Purwoko, A., Muntari, \& Haifaturrahmah. (2020). Development Of Subjects Specific Pedagogy To Build Environmental Awareness Character On Students In Mining Areas. Iop Conf. Series: Earth And Environmental Science, 413, 1-7. Https://Doi.Org/Doi:10.1088/1755-1315/413/1/012033

Romartu Situngkir. (2020). Modal Budaya Pada Komunitas Sekolah Adat Di Kecamatan Sianjur Mula Mula Kabupaten Samosir. Jom Fisip, $\quad 7(1), \quad 1-11$ Https://Jom.Unri.Ac.Id/Index.Php/Jomfsip/Article/View/26763

Widiana, F. H., \& Rosy, B. (2021). Pengembangan E-Modul Berbasis Flipbook Maker Pada Mata Pelajaran Teknologi Perkantoran. Edukatif: Jurnal Ilmu Pendidikan, 3(6), 3728-3739. Https://Www.Edukatif.Org/Index.Php/Edukatif/Article/View/1265 